\title{
Comparison of EGFR and K-RAS gene status between primary tumours and corresponding metastases in NSCLC
}

\author{
A Kalikaki', A Koutsopoulos' ${ }^{2}$, M Trypaki', J Souglakos' ${ }^{1,3}$, E Stathopoulos ${ }^{2}$, V Georgoulias ${ }^{1,3}$, D Mavroudis ${ }^{1,3}$ and \\ A Voutsina*,I
}

'Laboratory of Tumor Cell Biology, School of Medicine, University of Crete, Heraklion, Crete, Greece; ${ }^{2}$ Department of Pathology, University General

Hospital of Heraklion, Heraklion, Crete, Greece; ${ }^{3}$ Department of Medical Oncology, University General Hospital of Heraklion, Heraklion, Crete, Greece

In non-small-cell lung cancer (NSCLC), epidermal growth factor receptor (EGFR) and K-RAS mutations of the primary tumour are associated with responsiveness and resistance to tyrosine kinase inhibitors (TKIs), respectively. However, the EGFR and K-RAS mutation status in metastases is not well studied. We compared the mutation status of these genes between the primary tumours and the corresponding metastases of 25 patients. Epidermal growth factor receptor and K-RAS mutation status was different between primary tumours and corresponding metastases in 7 (28\%) and 6 (24\%) of the 25 patients, respectively. Among the 25 primary tumours, three 'hotspot' and two non-classical EGFR mutations were found; none of the corresponding metastases had the same mutation pattern. Among the five (20\%) K-RAS mutations detected in the primary tumours, two were maintained in the corresponding metastasis. Epidermal growth factor receptor and K-RAS mutations were detected in the metastatic tumours of three (12\%) and five (20\%) patients, respectively. The expressions of EGFR and phosphorylated EGFR showed 10 and $50 \%$ discordance, in that order. We conclude that there is substantial discordance in EGFR and K-RAS mutational status between the primary tumours and corresponding metastases in patients with NSCLC and this might have therapeutic implications when treatment with TKIs is considered.

British Journal of Cancer (2008) 99, 923-929. doi: I0.1038/sj.bjc.6604629 www.bjcancer.com

Published online 26 August 2008

(c) 2008 Cancer Research UK

Keywords: EGFR; K-RAS; mutations; primary tumour; metastasis; NSCLC

Lung cancer is the most frequent solid tumour and represents the leading cause of cancer death throughout the developed world. Almost $70 \%$ of patients with non-small-cell lung carcinoma (NSCLC) present with locally advanced or metastatic disease at the time of diagnosis. Non-small-cell lung carcinoma is characterised by the accumulation of multiple genetic alterations (Marsit et al, 2004; Yokota and Kohno, 2004; Garnis et al, 2006). Mutations within the tyrosine kinase domain of epidermal growth factor receptor (EGFR) account for increased sensitivity to tyrosine kinase inhibitors (TKIs; gefitinib and erlotinib) and they are associated with prolonged overall survival (Lynch et al, 2004; Paez et al, 2004; Perez-Soler et al, 2004; Chou et al, 2005; Taron et al, 2005; Hirsch, 2006). However, the point mutation T790M and an insertion mutation in exon 20 were associated with resistance to TKIs (Gazdar and Minna, 2005). Furthermore, recent studies have shown that the expression of EGFR as assessed by gene copy number, mRNA and protein levels could be used to predict responsiveness to therapy with TKIs (Hirsch et al, 2005; Taron et al, 2005; Dacic et al, 2006; Dziadziuszko et al, 2006; Endo et al, 2006). In addition, several clinicopathological characteristics, such as adenocarcinoma histology, non-smoking history, female gender and Asian origin, are also associated with a higher probability of response to TKIs, whereas the presence of $K-R A S$ mutations seems

*Correspondence: Dr A Voutsina; E-mail: georgsec@med.uoc.gr Received 2 May 2008; revised I August 2008; accepted I August 2008; published online 26 August 2008 to be correlated with primary resistance to these agents (Tokumo et al, 2005; Tsao et al, 2005; van Zandwijk et al, 2007). Thus, an emerging issue concerning EGFR-targeted therapy is to identify the best method for selecting patients who are more likely to benefit from EGFR inhibition.

Advanced NSCLC metastasises systemically to diverse sites, such as the brain, bone, adrenal glands and liver. The classical model for the metastatic process suggests that most cells of a given primary tumour have low metastatic potential and only a few cells acquire enough somatic mutations to become metastatic (Bernards and Weinberg, 2002). An alternative model proposes that the metastatic potential is encoded in the mass of a given primary tumour that has progressed to a pre-metastatic state, after which metastases may randomly occur without any further gene expression changes (van 't Veer et al, 2002; Hynes, 2003; Van't Veer and Weigelt, 2003). Taking into account these two models, a critical issue for the treatment of metastatic NSCLC is the question of genetic variability and differences between the primary tumour and the corresponding metastases. In the majority of studies, EGFR and K-RAS status was determined on the primary tumours and there are very few data concerning those of corresponding metastases (Italiano et al, 2006; Matsumoto et al, 2006). Therefore, it is unclear whether the same EGFR and K-RAS mutations are also present in the metastatic lesions or whether clones with different mutations are responsible for the generation of metastases.

In this study, the mutation status of EGFR and $K-R A S$ as well as the EGFR and p-EGFR expressions on the primary tumours and the corresponding metastatic lesions were evaluated in 25 patients 
with advanced NSCLC. The objective of this study was to investigate the prevalence of EGFR and $K-R A S$ mutations in metastases and to examine whether these mutations and the EGFR expression patterns are discordant between the primary tumours and the corresponding metastases. Secondary objectives were to explore whether the EGFR expression pattern correlated to EGFR and/or $K-R A S$ mutations in both the primary tumours and corresponding metastases.

\section{PATIENTS AND METHODS}

\section{Patients}

Patients, aged $>18$ years old, with histologically confirmed NSCLC who underwent biopsy or surgical excision of the primary tumour and the corresponding metastases were included in this retrospective analysis. Histological type was determined according to the World Health Organization criteria, and the stage of the disease corresponds to that of the time of primary diagnosis. Smoking history was obtained during the patient's first evaluation. All patients gave their informed consent for using their tumour sample for molecular and pathologic analysis. The study has been approved by the Ethics and Scientific Committees of our institution.

\section{DNA extraction and mutation analysis}

All tumour samples were formalin-fixed paraffin-embedded tissues. Sections of a paraffin block corresponding to one representative area of the tumour were stained with haematoxylin/eosin, and the presence of tumour tissue was verified by an experienced pathologist. Subsequently, tissue samples from at least three serial sections were microdissected (piezo power Eppendorf Microdissector; Eppendorf, Germany) to ensure that specimens contained at least $80 \%$ tumour cells; sections of $5 \mu \mathrm{m}$ thickness were also collected from adjacent normal tissue when available, extracted with xylene and ethanol to remove paraffin and placed in $1 \%$ SDS/proteinase $\mathrm{K}\left(10 \mathrm{mg} \mathrm{ml}^{-1}\right)$ at $56^{\circ} \mathrm{C}$ overnight. DNA was extracted using the MasterPure Complete DNA/RNA Purification kit (Epicentre Biotechnologies, Madison, WI, USA) according to the manufacturer's instructions. Exons 18, 19, 20 and 21 of the EGFR and exon 1 of K-RAS were sequentially amplified by two rounds of polymerase chain reaction (PCR) and subjected to direct sequencing. The PCR primers for EGFR amplification were as follows: 155273L23: $5^{\prime}$-TCCCAAACACTCAGTGAAACAAA-3'; 155348L22: 5'-TGGTCTCACAGGACCACTGATT-3'; 154838U22: 5' -TCAGAGC CTGTGTTTCTACCAA-3'; 154899U20: 5' -TCCAAATGAGCTGGCA AGTG-3'; 55634U24: 5'-AAATAATCAGTGTGATTCGTGGAG-3'; 156027L20: 5'-TGTGGAGATGAGCAGGGTCT-3'; 156107L22: 5'-G AGGCCAGTGCTGTCTCTAAGG-3'; 155750U20: 5'-GTGCATCGCT GGTAACATCC-3'; 173160L22: 5'-CAGCTCTGGCTCACACTACC AG-3'; 173076L19: 5'-CATCCTCCCCTGCATGTGT-3'; 172656U22: $5^{\prime}$-GCAGCGGGTTACATCTTCTTTC- ${ }^{\prime}$; and 172747U19: $5^{\prime}$-GCT CAGAGCCTGGCATGAA-3'. The PCR primers for $K-R A S$ amplification were as follows: RASU1: $5^{\prime}$-AGGCCTGCTGAAAATGAC TGAATA-3'; RASL1: 5'-CTGTATCAAAGAATGGTCCTGCAC-3'; RASU2: 5'-AAAATGACTGAATATAAACTTGTGG-3'; RASL2: 5'-C TCTATTGTTGGATCATATTCGTC- $3^{\prime}$. The first PCR was carried out in a total volume of $10 \mu \mathrm{l}$ contained $1 / 10$ of the extracted genomic DNA using $1 \mathrm{U}$ of Platinum Taq DNA polymerase (Invitrogen Corporation, Carlsbad, CA, USA). The initial denaturing step was at $94^{\circ} \mathrm{C}$ for $15 \mathrm{~min}$, followed by 35 cycles of denaturing step at $94^{\circ} \mathrm{C}$ for $20 \mathrm{~s}$, annealing step at $60^{\circ} \mathrm{C}$ for $30 \mathrm{~s}$ and extension step at $72^{\circ} \mathrm{C}$ for $1 \mathrm{~min}$, ending with a final extension step at $72^{\circ} \mathrm{C}$ for $7 \mathrm{~min}$. Nested PCR was carried out in a total volume of $20 \mu \mathrm{l}$ and the conditions were identical to the first PCR. The PCR products are directly sequenced by dye terminator sequencing
(ABI BigDye Terminator kit, v3.1, Applied Biosystems, Foster City, CA, USA), purified by ethanol precipitation and separated by capillary electrophoresis on an ABI 3100 Avant genetic analyzer (Applied Biosystems). Sequence analysis was carried out by Seqscape software (Applied Biosystems) and manually by two reviewers (AK and $\mathrm{AV})$. All sequence variations were confirmed by sequencing in both directions and by an independent PCR amplification when sufficient material was available.

The sensitivity of our methodology was evaluated by determining the minimum frequency of EGFR and $K-R A S$ mutations required for detection in our system. This was accomplished by performing mixing experiments using cell lines with and without EGFR (H2073-wt-EGFR and HCC827-Del19-EGFR) or K-RAS (H2073-wt-K-RAS and A549-G12D-K-RAS) mutations. These experiments demonstrated that the Del19 and $K-R A S$ mutations could be detected when present in 10 and $20 \%$ of the cells in the sample, respectively (data not shown).

\section{Immunohistochemistry for EGFR}

The paraffin-embedded tissues were cut at $4 \mu \mathrm{m}$ thickness and were deposited on SuperFrost/Plus Slides (O.Kindler GmbH, Freiburg, Germany). After deparaffinisation, the slides for EGFR were treated with proteinase K (Code S3020, DakoCytomation, Glostrup, Denmark) for $5 \mathrm{~min}$ at room temperature, and those for p-EGFR were treated with EDTA at pH 8 in a microwave oven three times for $5 \mathrm{~min}$ at $500 \mathrm{~W}$ for antigen retrieval. The primary antiEGFR antibody (mouse monoclonal, clone H11, code M3563, DakoCytomation) was used at a dilution of $1: 50(\mathrm{v} / \mathrm{v})$ and incubated for $1 \mathrm{~h}$ at room temperature. The primary anti-phospho-EGFR antibody (rabbit monoclonal, pY1173-EGFR, code no. 4407, Cell Signalling, Danvers, MA, USA) was used at a dilution of $1: 200(\mathrm{v} /$ v) and incubated overnight at $4{ }^{\circ} \mathrm{C}$. For the detection of antigenantibody reaction, the UltraVision detection system AP Polymer kit (Cat no. TL-125-AL, Lab Vision, Fremont, CA, USA) was used according to the manufacturer's instructions. Fast red was used as chromogen for $20 \mathrm{~min}$; the sections were counterstained with Mayer's haematoxylin for $3 \mathrm{~min}$, subsequently rinsed in ammonium and finally mounted with glycergel. A positive (an NSCLC tumour specimen with known positivity) and a negative (omission of primary antibody) control were used. The stained sections were independently evaluated by two pathologists (AK and ES). Immunoreactions of EGFR were graded as $3+$ when strong complete membrane staining was observed in more than $10 \%$ of the tumour cells, as $2+$ when more than $10 \%$ of the tumour cells showed weak-to-moderate complete membrane staining, as $1+$ when partially, faint membrane stain was detected in more than $10 \%$ of the tumour cells and as 0 when no staining at all or membrane staining in less than $10 \%$ of the tumour cells was observed. In this study, we arbitrarily classified EGFR expression status in two subsets; the $2+$ or $3+$ signals were considered as EGFR overexpression and the 0 or $1+$ signals as non-expression (Koutsopoulos et al, 2007).

A paraffin block from the HCC827 lung epithelial adenocarcinoma cell line and commercially available positive controls (SignalSlide Phospho-EGF Receptor (Tyr1173) IHC Controls, code no. 8102, Cell Signalling) was used to validate the antibody for p-EGFR. pY1173-EGFR immunostaining was mainly membranous and was graded as 0 ( $<5 \%$ positive cells), $1+(5-19 \%$ positive cells), $2+(20-50 \%$ positive cells $)$ and $3+(>50 \%$ positive cells $)$ (Cortas et al, 2007).

\section{Statistical analysis}

McNemar test was used to compare the EGFR and K-RAS status between primary tumours and related metastatic sites. Differences were considered statistically significant when the $P$-value was $<0.05$. All statistical tests were two-sided. 


\section{RESULTS}

\section{Patient characteristics}

Twenty-two (88\%) patients were men and $22(88 \%)$ were active or former smokers and their median age was 55 years (range, 41-70). Eighteen (72\%) patients had adenocarcinomas (ADC) and 21 (84\%) patients had stage III or IV disease. Among the 50 samples analysed (25 primary tumours and 25 metastases), $26(52 \%)$ samples were surgical and $24(48 \%)$ biopsies. The primary tumour tissue was the lung $(n=25$ patients); and the origin of the metastatic sample was lung $(n=9$ patients), thoracic wall $(n=5$ patients), adrenal gland ( $n=4$ patients), brain ( $n=3$ patients), bone ( $n=2$ patients), liver ( $n=1$ patient) and skin ( $n=1$ patient). Metastases were metachronous in all cases; the median time elapsed between resection of the primary tumour and the corresponding metastatic site was 30 months (range, 4-143). The patients' clinicopathologic characteristics are presented in Table 1 . Nine $(36 \%)$ patients were treated with gefitinib in the context of an Expanded Access Program (Table 2).

\section{EGFR mutation status of the primary tumours and the corresponding metastasis}

The EGFR mutation status of the primary tumours and the corresponding metastases is presented in Table 2. Epidermal growth factor receptor mutations were detected in the primary tumours of five $(20 \%)$ patients; of these, three of them were the well-characterised 'hotspot' mutations in exon 19 (Del746-750 and E746V; case nos. 20, 23 and 18) and the remaining two were novel point mutations in exons 18 and 21 (L692P and G857E; case nos. 17 and 19), respectively. The corresponding metastases of the Del746750 (case no. 23), E746V (no. 18), L692P (no. 17) and G857E (no. 19 ) mutant primary tumours were wild type with respect to $E G F R$ mutation status. Epidermal growth factor receptor mutations were detected in the metastatic tumours of three (12\%) patients (Table 2). The metastasis of one of these patients showed the same EGFR mutation (Del19) as the primary tumour as well as an additional one, the T790M in exon 20 (no. 20); conversely, the other two patients carried two novel mutations in exon 18 (L692P and V717A; no. 12) and the T847A (no. 13) in exon 21, which could not be detected in the patients' primary tumour samples. We have confirmed that the non-classical mutations detected in our series are not single nucleotide polymorphisms by mutation analysis of matched normal tissue or blood (data not shown).

Consequently, the EGFR gene status could be classified as: (i) EGFR wild type in both primary tumour and metastasis $(n=18$ patients; 72\%), and (ii) EGFR mutations detected only in the primary tumour $(n=4$ patients; $16 \%)$ or the metastases $(n=2$ patients; $8 \%)$ or both ( $n=1$ patient; $4 \%)$. Therefore, EGFR mutation status showed a discordance of $28 \%$ (7 of 25 patients) (McNemar test, $P=0.688$ ) between the primary tumour and corresponding metastasis (Table 3 ).

\section{EGFR and p-EGFR expression by IHC in the primary tumour and the corresponding metastases}

Én 19 patients sufficient tumour tissue was available for immunohistochemical analysis of EGFR (Tables 2 and 4). The incidence of EGFR overexpression (grade $2+, 3+$ ) was $26.5 \%$ in both primary and metastatic tumours. Concordance between the primary tumour and the corresponding metastases was observed in 17 (89.5) patients (Cohen's Kappa $=0.729, P=0.001$ ) and among them EGFR was overexpressed in four (21.1\%). Discordance was observed in two (10.5\%) patients (nos. 14 and 15) (McNemar test, $P=1$ ). Evaluable paired tissue specimens for p-EGFR analysis by IHC were available in 16 patients. Three out of $16(18.8 \%)$ primary

Table I Patient's clinicopathological characteristics

\begin{tabular}{|c|c|c|c|c|c|c|c|c|c|}
\hline Case & Age & Sex & Histology & Stage $^{a}$ & $\begin{array}{l}\text { Smoking } \\
\text { status }\end{array}$ & $\begin{array}{l}\text { Tissue sample } \\
\mathbf{P}^{\mathrm{c}} / \mathbf{M}^{\mathrm{d}}\end{array}$ & $\begin{array}{l}\text { Metastatic } \\
\text { site }\end{array}$ & $\begin{array}{c}\text { Time }^{\mathbf{e}} \\
\text { elapsed between } \\
\mathbf{P} \text { and } \mathbf{M}\end{array}$ & $\begin{array}{l}\text { Treatment administered } \\
\text { between } P \text { and } M\end{array}$ \\
\hline 1 & 60 & $M$ & ADC & IV & Active & $\mathrm{B} / \mathrm{B}$ & Skin & 10 & Taxane-platinum \\
\hline 2 & 54 & $M$ & $\mathrm{SCC}$ & $\|$ & Active & $\mathrm{S} / \mathrm{S}$ & Lung & 20 & None \\
\hline 3 & 70 & $M$ & ADC & III & Former & $\mathrm{B} / \mathrm{B}$ & Lung & 55 & Taxane-gemcitabine \\
\hline 4 & 44 & M & ADC & III & Active & $\mathrm{S} / \mathrm{B}$ & Lung & 65 & $\begin{array}{l}\text { Taxane-platinum- } \\
\text { gemcitabine }\end{array}$ \\
\hline 5 & 55 & $M$ & ADC & III & Active & $\mathrm{S} / \mathrm{S}$ & Lung & 23 & Taxane-platinum \\
\hline 6 & 63 & $M$ & ADC & IV & Active & $\mathrm{B} / \mathrm{B}$ & Lung & 4 & None \\
\hline 7 & 66 & $M$ & ADC/BAC & III & Never & $\mathrm{S} / \mathrm{B}$ & Thoracic wall & 12 & None \\
\hline 8 & 57 & $M$ & LCC & III & Active & $\mathrm{S} / \mathrm{B}$ & Thoracic wall & 4 & Taxane-platinum \\
\hline 9 & 55 & $M$ & ADC & III & Former & $\mathrm{S} / \mathrm{S}$ & Thoracic wall & 15 & Taxane-platinum \\
\hline 10 & 49 & $M$ & ADC & $\|$ & Active & $\mathrm{S} / \mathrm{S}$ & Adrenal gland & 28 & Taxane-platinum \\
\hline | | & 50 & $\mathrm{~F}$ & ADC & IV & Active & $\mathrm{B} / \mathrm{B}$ & Brain & 36 & Taxane-platinum \\
\hline 12 & 68 & $M$ & ADC & III & Active & $\mathrm{S} / \mathrm{S}$ & Brain & 10 & Taxane-platinum \\
\hline 13 & 44 & $M$ & GCC & IV & Active & $\mathrm{B} / \mathrm{B}$ & Lung & 74 & Taxane-platinum \\
\hline 14 & 56 & $M$ & ADC & IV & Active & $\mathrm{B} / \mathrm{S}$ & Adrenal gland & 17 & None \\
\hline 15 & 53 & $M$ & ADC & III & Active & $\mathrm{S} / \mathrm{B}$ & Thoracic wall & 2 & Taxane-platinum \\
\hline 16 & 41 & $M$ & ADC & IV & Active & $\mathrm{S} / \mathrm{B}$ & Lung & 143 & None \\
\hline 17 & 56 & $M$ & ADC & IV & Former & $\mathrm{B} / \mathrm{S}$ & Adrenal gland & 36 & $\begin{array}{l}\text { Taxane-platinum- } \\
\text { gemcitabine, gefitinib }\end{array}$ \\
\hline 18 & 42 & $\mathrm{~F}$ & ADC & $\|$ & Never & $\mathrm{S} / \mathrm{S}$ & Liver & 30 & Taxane-platinum, gefitinib \\
\hline 19 & 55 & $M$ & ADC & III & Former & $S / B$ & Bone & 2 & None \\
\hline 20 & 46 & $M$ & $\mathrm{SCC}$ & III & Active & $\mathrm{S} / \mathrm{B}$ & Lung & 45 & Taxane-platinum-gefitinib \\
\hline 21 & 62 & M & LCC & III & Never & $\mathrm{S} / \mathrm{B}$ & Bone & 48 & Platinum - gemcitabine \\
\hline 22 & 67 & M & ADC & IV & Active & $\mathrm{B} / \mathrm{S}$ & Adrenal gland & 14 & None \\
\hline 23 & 53 & $M$ & ADC & IV & Active & $\mathrm{S} / \mathrm{B}$ & Brain & 21 & None \\
\hline 24 & 52 & $\mathrm{~F}$ & ADC/BAC & $\|$ & Active & $\mathrm{S} / \mathrm{S}$ & Lung & 51 & None \\
\hline 25 & 63 & $M$ & ADC & IV & Active & $B / B$ & Thoracic wall & 1 & None \\
\hline
\end{tabular}

$\mathrm{ADC}=$ adenocarcinoma; $\mathrm{ADC} / \mathrm{BAC}=$ adenocarcinoma with bronchoalveolar features; $\mathrm{GCC}=$ giant cell carcinoma; $\mathrm{LCC}=$ large cell carcinoma; $\mathrm{F}=$ female; $\mathrm{M}=$ male;

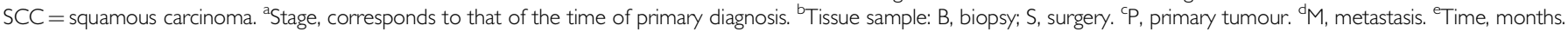


Table 2 EGFR and K-RAS status in paired primary and metastatic tumours

\begin{tabular}{|c|c|c|c|c|c|c|c|c|c|c|}
\hline \multirow[b]{2}{*}{ Case } & \multicolumn{2}{|c|}{ EGFR mutation status } & \multicolumn{2}{|c|}{ EGFR expression } & \multicolumn{2}{|c|}{ p-EGFR expression } & \multicolumn{2}{|c|}{ K-RAS mutation status } & \multirow[b]{2}{*}{ Gefitinib } & \multirow[b]{2}{*}{ Response } \\
\hline & Primary & Metastasis & Primary & Metastasis & Primary & Metastasis & Primary & Metastasis & & \\
\hline 2 & wt & wt & $3+$ & $3+$ & $1+$ & $1+$ & wt & wt & No & - \\
\hline 3 & wt & wt & 0 & $1+$ & 0 & 0 & wt & wt & No & - \\
\hline 4 & wt & wt & $3+$ & $2+$ & 0 & $1+$ & wt & wt & No & - \\
\hline 5 & wt & wt & 0 & 0 & 0 & 0 & wt & wt & No & - \\
\hline 8 & wt & wt & $1+$ & 0 & 0 & 0 & GI2S & wt & No & - \\
\hline 9 & wt & wt & $1+$ & $1+$ & 0 & $1+$ & wt & GI3S & No & - \\
\hline 10 & wt & wt & $2+$ & $3+$ & 0 & 0 & GI2V & GI2V & No & - \\
\hline 11 & wt & wt & ND & $2+$ & ND & $2+$ & wt & GI2S & No & - \\
\hline 12 & wt & $\begin{array}{l}\text { L692P } \\
\text { V717A }\end{array}$ & $1+$ & 0 & ND & $2+$ & wt & wt & No & - \\
\hline 13 & wt & T847A & 0 & 0 & 0 & $1+$ & wt & wt & No & - \\
\hline 19 & G857E & wt & 0 & 0 & 0 & $1+$ & wt & wt & Yes & SD \\
\hline 20 & $\begin{array}{l}\text { E746-A750 } \\
\text { del }\end{array}$ & $\begin{array}{l}\text { E746-A750 } \\
\text { del T790M }\end{array}$ & $2+$ & $3+$ & $2+$ & 0 & wt & wt & Yes & SD \\
\hline 21 & wt & wt & ND & ND & ND & ND & wt & wt & No & - \\
\hline 22 & wt & wt & ND & ND & ND & ND & GI2D & wt & Yes & PD \\
\hline 23 & $\begin{array}{l}\text { E746-A750 } \\
\text { del }\end{array}$ & wt & ND & ND & ND & ND & GI2C & GI2C & Yes & SD \\
\hline 24 & wt & wt & ND & ND & ND & ND & wt & wt & No & - \\
\hline 25 & wt & wt & ND & ND & ND & ND & GI2C & wt & No & - \\
\hline
\end{tabular}

Table 3 Combined analysis of EGFR and K-RAS mutation status

\begin{tabular}{llllll}
\hline & \multicolumn{4}{c}{ Primary/metastatic tumour } & \\
\cline { 2 - 5 } & $\mathbf{w t} / \mathbf{w t}$ & $\mathbf{w t} / \mathbf{m u t}$ & $\mathbf{m u t} / \mathbf{w t}$ & $\mathbf{m u t} / \mathbf{m u t}$ & Discordance \\
\hline EGFR & $18(72 \%)$ & $2(8 \%)$ & $4(16 \%)$ & $1(4 \%)^{\mathrm{a}}$ & 7 cases $(28 \%)$ \\
K-RAS & $17(68 \%)$ & $3(12 \%)$ & $3(12 \%)$ & $2(8 \%)$ & 6 cases $(24 \%)$ \\
\hline
\end{tabular}

a Dell 9/Dell 9 and T790M.

Table 4 EGFR expression as assessed by $\| \mathrm{HC}$

\begin{tabular}{|c|c|c|c|c|c|}
\hline & \multicolumn{4}{|c|}{ Primary tumour status/metastasis status } & \multirow[b]{2}{*}{ Discordance } \\
\hline & +ve/+ve & $-\mathbf{v e l}-\mathbf{v e}$ & +vel-ve & -ve/+ve & \\
\hline $\begin{array}{l}\text { EGFR } \\
\text { p-EGFR (Y||73) }\end{array}$ & $\begin{array}{l}4(21.1 \%) \\
\mid(6.2 \%)\end{array}$ & $\begin{array}{r}13(68.4 \%) \\
7(43.8 \%)\end{array}$ & $\begin{array}{l}\text { I }(5.3 \%) \\
2(12.5 \%)\end{array}$ & $\begin{array}{l}\text { I }(5.3 \%) \\
6(37.5 \%)\end{array}$ & $\begin{array}{l}2 / 19(10.6 \%) \\
8 / 16(50 \%)\end{array}$ \\
\hline
\end{tabular}

$\mathrm{IHC}=$ immunohistochemistry.

and seven out of $16(43.8 \%)$ metastatic tumours expressed phosphorylated EGFR (pY1173-EGFR-positive). Discordance between the primary and metastatic tumours was observed in eight $(50 \%)$ patients $(\mathrm{McNemar}$ test, $P=1)$ (Tables 2 and 4$)$. There was no correlation between the expression of EGFR and pY1173-EGFR. In order to confirm our findings, we repeated the immunohistochemistry from serial sections in all tumour specimens that exhibited EGFR-negative and p-EGFR-positive staining and the obtained results were identical. Epidermal growth factor receptor gene copy number was also investigated by fluorescence in situ hybridisation in eight patients (nos. 2, 5, 7, 9, 10, 13, 19 and 24) for whom paired tissue specimens were available; amplification of EGFR gene was not detected in any of these tumour specimens.

\section{$K-R A S$ mutation status of the primary tumours and the corresponding metastases}

Primary and metastatic tumours were also assessed for $K$-RAS mutations (Table 2). K-RAS mutations were detected in the primary tumours of five (20\%) patients (nos. 8, 10, 22, 23 and 25) and in the metastatic tumours of five (20\%) patients (nos. 9, 10, 11, 16 and 23), respectively. Two patients (nos. 10 and 23) carried the same $K-R A S$ mutations in both primary and metastatic tumours (Table 2). One of them (case no. 23) carried the Del746-750 EGFR mutation in the primary tumour but not in metastasis. This was confirmed by three independent PCRs from three genomic DNAs extracted from serial sections of the paraffin blocks. Discordance in $K-R A S$ mutation status between the primary tumours and the corresponding metastases was observed in six (24\%) patients (McNemar test, $P=1$ ) (Table 3 ).

\section{Response to gefitinib according to EGFR and $K-R A S$ mutation status}

Nine patients received gefitinib as first (nos. 23 and 18), third (nos. 15, 16, 1920 and 22) or fourth (nos. 14 and 17) line treatment. Three patients received gefitinib before the biopsy of metachronous metastases (nos. 17, 18 and 20) and six received gefitinib after the biopsy of metastases (nos. 14, 15, 16, 19, 22 and 23). Five patients (56\%) achieved stable disease and four (44\%) progressive disease (Table 2). All patients who experienced progressive disease on gefitinib were wild type regarding the EGFR mutation status in both primary tumours and metastases (nos. 14, 15, 16, and 22), of these, two patients carried $K-R A S$ mutations in the primary 
tumour (no. 22) or metastasis (no. 16). All the five patients with stable disease on gefitinib carried EGFR mutations in their primary tumours (nos. 17, 18, 19, 20 and 23). Of these, three patients carried the well-characterised activating mutations in exon 19 (nos. 18, 20 and 23) and two carried EGFR mutations of unknown function (nos. 17 and 19). Patient nos. 18 and 20 who received gefitinib before metachronous metastasis developed metastatic tumours, which were either wild type in respect to EGFR mutation status (no. 18) or had acquired resistance because of the T790M EGFR mutation (no. 20). Patient no. 23, who received gefitinib after metastasis, carried both EGFR and K-RAS mutations in the primary tumour and the same $K-R A S$ mutation in metastasis.

\section{DISCUSSION}

Several studies have shown that activating EGFR mutations in exons 18, 19 and 21 have been associated with a $75-95 \%$ objective response rate with EGFR TKIs, whereas the K-RAS mutations were associated with a lack of sensitivity to these agents (Pao et al, 2005; Sharma et al, 2007). Epidermal growth factor receptor gene amplification and protein expression have also been considered as predictors of clinical benefit with gefitinib (Hirsch et al, 2006). However, in clinical studies, a significant percentage of patients presented clinical benefit when treated with TKIs irrespective of the expression and mutational status of EGFR (Sharma et al, 2007). As, in most studies, EGFR expression and mutations were determined on the primary tumour, the observed clinical benefit of patients with wild-type EGFR or the absence of response to TKIs of patients with EGFR mutations could be due to discordance in the EGFR mutation status or expression between the primary tumour and the corresponding metastasis.

This study demonstrated the existence of a significant discordance of EGFR and $K-R A S$ mutations occurring in primary tumours and their corresponding metastases in patients with NSCLC. The discordance in EGFR mutation status was $28 \%$ and that in $K-R A S$ was $24 \%$. Similarly, two other studies in paired NSCLC tumours showed a discordance of 32 and $27 \%$ regarding the EGFR gene copy number (Italiano et al, 2006; Bozzetti et al, 2008), whereas another study including six NSCLC patients of Asian ethnicity reported a $100 \%$ concordance in regard to EGFR mutation status (Matsumoto et al, 2006). This discrepancy could be related to the different sites of the metastatic tumours analysed in this study (five different distant metastases), whereas in the Matsumoto's et al study, only tumour samples from brain metastases were included. Diverse sites of metastases in NSCLC probably represent different clonal outgrowths. Alternatively, we cannot exclude that the different ethnicity of patients and/or the different types of EGFR mutations could be the reason for this discrepancy (Tsao et al, 2006; Pallis et al, 2007). In this study including only Caucasian patients, three classical activating (Del19 and E746V) and four non-classical mutations (T847A, L692PV717A, L692P and G857E) were detected, whereas in Matsumoto's et al study, only classical activating Del19 and L858R mutations were reported. Concerning the non-classical mutations, it is unlikely to represent PCR artifacts, as L692F, T847I and G857E EGFR mutations have been previously reported (Fujimoto et al, 2005; Tsao et al, 2005; Hsieh et al, 2006). Furthermore, the expression of phosphorylated EGFR (pY1173-EGFR-positive) on tumour cells from metastatic lesions carrying the T847A and L692P-V717A mutations strongly suggests that the former might be activating EGFR mutation. The time elapsed between diagnoses of the primary tumour and corresponding metastasis in patients (nos. 13 and 12) carrying the abovementioned mutations was 74.5 and 10 months, respectively. Therefore, acquisition of new mutations may be developed during the evolution of the metastatic process.
The administration of TKIs could be an additional explanation of the observed discordance of EGFR mutations. Three out of 25 patients received gefitinib before the development of a metachronous metastasis, whereas none of the patients reported in the Matsumoto's et al study had exposed to TKIs. It is known that NSCLC patients with EGFR-dependent primary tumours when treated with TKIs can develop metastases, in which either the EGFR signalling is negated or resistance is acquired due to secondary EGFR mutations like T790M or MET amplification (Daneshmand et al, 2003; Gazdar and Minna, 2005; Engelman et al, 2007; Lutterbach et al, 2007). It is interesting to note that in patients who had not been exposed to TKIs before biopsy of metastatic lesions, a $18 \%$ (4 out of 22 patients) discordance was observed between primary tumours and related metastases. However, a final explanation of the observed discordance, which cannot be excluded, concerns the low-frequency intratumoral heterogeneity for the occurrence of EGFR mutations (Sakurada et al, 2008).

Our findings concerning the $K-R A S$ mutation status are in agreement with a previous study demonstrating that the $K-R A S$ mutational status of the primary tumour does not always predict the status of bone metastasis in NSCLC (Badalian et al, 2007). A similar phenomenon was also reported in patients with colorectal cancer (Tortola et al, 2001). Although K-RAS mutations seem to be associated with the early development of NSCLC, it cannot be excluded that $K-R A S$ mutations are lost later during tumour progression (Burmer and Loeb, 1989; Li et al, 1994). This may, in part, explain the discordance in the $K-R A S$ mutation status between primary tumours and metachronous metastases.

Another possibility for the observed discordance in the EGFR and $K-R A S$ mutation status could be related to the administered chemotherapy. However, as shown in Table 1, among the 10 patients who had not received any treatment before the mutation analysis of the metastatic lesions, 5 developed metastases with different mutation status from that of the corresponding primary tumours. Thus, although tumour clone selection through the various treatments could be an explanation for the different molecular pattern in the primary tumour and metastatic site, our findings suggest that the metastasis genotype could be different from that of the corresponding primary tumour irrespectively of administered chemotherapy.

Previous studies have shown that EGFR and K-RAS mutations are mutually exclusive, suggesting the presence of different pathways of lung carcinogenesis. However, as previously reported, our data show that $K-R A S$ mutation may coexist with EGFR mutation (Fujimoto et al, 2005; Han et al, 2006). Among the five patients with EGFR mutations in primary tumours, one patient concomitantly had K-RAS mutation (G12C with deletion in exon 19). In the metachronous metastasis, only the K-RAS mutation was retained. This patient received gefitinib after the biopsy of metastatic lesion and had stable disease lasting for 3.5 months. The limited duration of response is compatible with the knowledge that the presence of $K-R A S$ mutations is associated with resistance to TKIs.

In this study, the expression of pY1173-EGFR was different between primary tumours and corresponding metastases in eight (50\%) patients, whereas EGFR expression was discordant in two (10\%) patients. The apparent lack of correlation between EGFR and p-EGFR expression has been previously reported and could be due to the different scoring systems and different sensitivities of antibodies used to evaluate the EGFR and p-EGFR expressions (Han et al, 2005). It is well known that overexpression of EGFR is associated with Tyr phosphorylation of the receptor proteins and that mutations in the kinase domain may cause constitutive phosphorylation of EGFR (Chen et al, 2006). However, biochemical studies have shown that variable phosphorylation rates were associated with different tyrosine phosphorylation sites in the receptor; G719S mutant receptor had less EGF-induced 
phosphorylation at Y845, Y992, Y1068 and Y1173 than did wildtype EGFR, whereas L858R mutant receptor preferentially phosphorylated at the Y1068 but not at Y1173 (Sordella et al, 2004; Chen et al, 2006; Liu et al, 2007).

Clinical investigations suggested a correlation between a high $E G F R$ gene copy number and EGFR mutations (Cappuzzo et al, 2005; Takano et al, 2005). Our study failed to demonstrate such a correlation probably due to limited number of cases analysed. Evaluable paired tissue specimens for fluorescence in situ hybridisation analysis were available for eight patients. Among them, two (nos 13 and 19) patients presented different EGFR mutation status in the primary tumours and corresponding metastases; however, these two patients harbour non-classical EGFR mutations (T847A and G857E) and did not show different EGFR amplification patterns between paired samples. On the basis of these findings, at the present time, we consider that only the genetic differences unequivocally distinguish EGFR-dependent tumours, which are likely to be sensitive to TKIs from the tumours that could be resistant to these agents (Papadopoulos et al, 2006).

In conclusion, our findings indicate a substantial discordance of $E G F R$ and $K-R A S$ mutations between the primary tumours and the corresponding metastases in NSCLC and underline the need to consider the genotype of both primary and metastatic tumours for selecting patients who will respond to therapy with TKIs.

\section{ACKNOWLEDGEMENTS}

This study was supported by a research grant from the Cretan Association for Biomedical Research (CABR).

\section{REFERENCES}

Badalian G, Barbai T, Raso E, Derecskei K, Szendroi M, Timar J (2007) Phenotype of bone metastases of non-small cell lung cancer: epidermal growth factor receptor expression and K-RAS mutational status. Pathol Oncol Res 13: 99 - 104

Bernards R, Weinberg RA (2002) A progression puzzle. Nature 418: 823

Bozzetti C, Tiseo M, Lagrasta C, Nizzoli R, Guazzi A, Leonardi F, Gasparro D, Spiritelli E, Rusca M, Carbognani P, Majori M, Franciosi V, Rindi G, Ardizzoni A (2008) Comparison between epidermal growth factor receptor (EGFR) gene expression in primary non-small cell lung cancer (NSCLC) and in fine-needle aspirates from distant metastatic sites. J Thorac Oncol 3: 18-22

Burmer GC, Loeb LA (1989) Mutations in the KRAS2 oncogene during progressive stages of human colon carcinoma. Proc Natl Acad Sci USA 86: $2403-2407$

Cappuzzo F, Hirsch FR, Rossi E, Bartolini S, Ceresoli GL, Bemis L, Haney J, Witta S, Danenberg K, Domenichini I, Ludovini V, Magrini E, Gregorc V, Doglioni C, Sidoni A, Tonato M, Franklin WA, Crino L, Bunn Jr PA, Varella-Garcia M (2005) Epidermal growth factor receptor gene and protein and gefitinib sensitivity in non-small-cell lung cancer. J Natl Cancer Inst 97: 643-655

Chen YR, Fu YN, Lin CH, Yang ST, Hu SF, Chen YT, Tsai SF, Huang SF (2006) Distinctive activation patterns in constitutively active and gefitinib-sensitive EGFR mutants. Oncogene 25: 1205-1215

Chou TY, Chiu CH, Li LH, Hsiao CY, Tzen CY, Chang KT, Chen YM, Perng RP, Tsai SF, Tsai CM (2005) Mutation in the tyrosine kinase domain of epidermal growth factor receptor is a predictive and prognostic factor for gefitinib treatment in patients with non-small cell lung cancer. Clin Cancer Res 11: 3750-3757

Cortas T, Eisenberg R, Fu P, Kern J, Patrick L, Dowlati A (2007) Activation state EGFR and STAT-3 as prognostic markers in resected non-small cell lung cancer. Lung Cancer 55: 349-355

Dacic S, Flanagan M, Cieply K, Ramalingam S, Luketich J, Belani C, Yousem SA (2006) Significance of EGFR protein expression and gene amplification in non-small cell lung carcinoma. Am J Clin Pathol 125: 860-865

Daneshmand M, Parolin DA, Hirte HW, Major P, Goss G, Stewart D, Batist G, Miller Jr WH, Matthews S, Seymour L, Lorimer IA (2003) A pharmacodynamic study of the epidermal growth factor receptor tyrosine kinase inhibitor ZD1839 in metastatic colorectal cancer patients. Clin Cancer Res 9: $2457-2464$

Dziadziuszko R, Witta SE, Cappuzzo F, Park S, Tanaka K, Danenberg PV, Baron AE, Crino L, Franklin WA, Bunn Jr PA, Varella-Garcia M, Danenberg KD, Hirsch FR (2006) Epidermal growth factor receptor messenger RNA expression, gene dosage, and gefitinib sensitivity in nonsmall cell lung cancer. Clin Cancer Res 12: 3078-3084

Endo K, Sasaki H, Yano M, Kobayashi Y, Yukiue H, Haneda H, Suzuki E, Kawano O, Fujii Y (2006) Evaluation of the epidermal growth factor receptor gene mutation and copy number in non-small cell lung cancer with gefitinib therapy. Oncol Rep 16: $533-541$

Engelman JA, Zejnullahu K, Mitsudomi T, Song Y, Hyland C, Park JO, Lindeman N, Gale CM, Zhao X, Christensen J, Kosaka T, Holmes AJ, Rogers AM, Cappuzzo F, Mok T, Lee C, Johnson BE, Cantley LC, Janne PA (2007) MET amplification leads to gefitinib resistance in lung cancer by activating ERBB3 signaling. Science 316: 1039-1043
Fujimoto N, Wislez M, Zhang J, Iwanaga K, Dackor J, Hanna AE, Kalyankrishna S, Cody DD, Price RE, Sato M, Shay JW, Minna JD, Peyton M, Tang X, Massarelli E, Herbst R, Threadgill DW, Wistuba II, Kurie JM (2005) High expression of ErbB family members and their ligands in lung adenocarcinomas that are sensitive to inhibition of epidermal growth factor receptor. Cancer Res 65: 11478-11485

Garnis C, Lockwood WW, Vucic E, Ge Y, Girard L, Minna JD, Gazdar AF, Lam S, MacAulay C, Lam WL (2006) High resolution analysis of nonsmall cell lung cancer cell lines by whole genome tiling path array CGH. Int J Cancer 118: $1556-1564$

Gazdar AF, Minna JD (2005) Inhibition of EGFR signaling: all mutations are not created equal. PLoS Med 2: e377

Han SW, Hwang PG, Chung DH, Kim DW, Im SA, Kim YT, Kim TY, Heo DS, Bang YJ, Kim NK (2005) Epidermal growth factor receptor (EGFR) downstream molecules as response predictive markers for gefitinib (Iressa, ZD1839) in chemotherapy-resistant non-small cell lung cancer. Int J Cancer 113: $109-115$

Han SW, Kim TY, Jeon YK, Hwang PG, Im SA, Lee KH, Kim JH, Kim DW, Heo DS, Kim NK, Chung DH, Bang YJ (2006) Optimization of patient selection for gefitinib in non-small cell lung cancer by combined analysis of epidermal growth factor receptor mutation, K-ras mutation, and Akt phosphorylation. Clin Cancer Res 12: $2538-2544$

Hirsch FR (2006) EGFR: a prognostic and/or a predictive marker? J Thorac Oncol 1: $395-397$

Hirsch FR, Varella-Garcia M, Bunn Jr PA, Franklin WA, Dziadziuszko R, Thatcher N, Chang A, Parikh P, Pereira JR, Ciuleanu T, von Pawel J, Watkins C, Flannery A, Ellison G, Donald E, Knight L, Parums D, Botwood N, Holloway B (2006) Molecular predictors of outcome with gefitinib in a phase III placebo-controlled study in advanced non-smallcell lung cancer. J Clin Oncol 24: 5034-5042

Hirsch FR, Varella-Garcia M, McCoy J, West H, Xavier AC, Gumerlock P, Bunn Jr PA, Franklin WA, Crowley J, Gandara DR (2005) Increased epidermal growth factor receptor gene copy number detected by fluorescence in situ hybridization associates with increased sensitivity to gefitinib in patients with bronchioloalveolar carcinoma subtypes: a Southwest Oncology Group Study. J Clin Oncol 23: 6838-6845

Hsieh MH, Fang YF, Chang WC, Kuo HP, Lin SY, Liu HP, Liu CL, Chen HC, Ku YC, Chen YT, Chang YH, Chen YT, Hsi BL, Tsai SF, Huang SF (2006) Complex mutation patterns of epidermal growth factor receptor gene associated with variable responses to gefitinib treatment in patients with non-small cell lung cancer. Lung Cancer 53(3): 311 - 322

Hynes RO (2003) Metastatic potential: generic predisposition of the primary tumor or rare, metastatic variants or both? Cell 113: $821-823$

Italiano A, Vandenbos FB, Otto J, Mouroux J, Fontaine D, Marcy PY, Cardot N, Thyss A, Pedeutour F (2006) Comparison of the epidermal growth factor receptor gene and protein in primary non-small-cell-lung cancer and metastatic sites: implications for treatment with EGFRinhibitors. Ann Oncol 17: $981-985$

Koutsopoulos AV, Mavroudis D, Dambaki KI, Souglakos J, Tzortzaki EG, Drositis J, Delides GS, Georgoulias V, Stathopoulos EN (2007) Simultaneous expression of c-erbB-1, c-erbB-2, c-erbB-3 and c-erbB-4 receptors in non-small-cell lung carcinomas: correlation with clinical outcome. Lung Cancer 57(2): 193-200 
Li S, Rosell R, Urban A, Font A, Ariza A, Armengol P, Abad A, Navas JJ, Monzo M (1994) K-ras gene point mutation: a stable tumor marker in non-small cell lung carcinoma. Lung Cancer 11: 19-27

Liu Y, Purvis J, Shih A, Weinstein J, Agrawal N, Radhakrishnan R (2007) A multiscale computational approach to dissect early events in the Erb family receptor mediated activation, differential signaling, and relevance to oncogenic transformations. Ann Biomed Eng 35: 1012-1025

Lutterbach B, Zeng Q, Davis LJ, Hatch H, Hang G, Kohl NE, Gibbs JB, Pan BS (2007) Lung cancer cell lines harboring MET gene amplification are dependent on Met for growth and survival. Cancer Res 67: 2081-2088

Lynch TJ, Bell DW, Sordella R, Gurubhagavatula S, Okimoto RA, Brannigan BW, Harris PL, Haserlat SM, Supko JG, Haluska FG, Louis DN, Christiani DC, Settleman J, Haber DA (2004) Activating mutations in the epidermal growth factor receptor underlying responsiveness of non-small-cell lung cancer to gefitinib. $N$ Engl J Med 350: 2129-2139

Marsit CJ, Hasegawa M, Hirao T, Kim DH, Aldape K, Hinds PW, Wiencke JK, Nelson HH, Kelsey KT (2004) Loss of heterozygosity of chromosome 3 p21 is associated with mutant TP53 and better patient survival in nonsmall-cell lung cancer. Cancer Res 64: $8702-8707$

Matsumoto S, Takahashi K, Iwakawa R, Matsuno Y, Nakanishi Y, Kohno T, Shimizu E, Yokota J (2006) Frequent EGFR mutations in brain metastases of lung adenocarcinoma. Int J Cancer 119: 1491 - 1494

Paez JG, Janne PA, Lee JC, Tracy S, Greulich H, Gabriel S, Herman P, Kaye FJ, Lindeman N, Boggon TJ, Naoki K, Sasaki H, Fujii Y, Eck MJ, Sellers WR, Johnson BE, Meyerson M (2004) EGFR mutations in lung cancer: correlation with clinical response to gefitinib therapy. Science 304: 1497-1500

Pallis AG, Voutsina A, Kalikaki A, Souglakos J, Briasoulis E, Murray S, Koutsopoulos A, Tripaki M, Stathopoulos E, Mavroudis D, Georgoulias V (2007) 'Classical' but not 'other' mutations of EGFR kinase domain are associated with clinical outcome in gefitinib-treated patients with nonsmall cell lung cancer. Br J Cancer 97: 1560-1566

Pao W, Wang TY, Riely GJ, Miller VA, Pan Q, Ladanyi M, Zakowski MF, Heelan RT, Kris MG, Varmus HE (2005) KRAS mutations and primary resistance of lung adenocarcinomas to gefitinib or erlotinib. PLoS Med 2: e17

Papadopoulos N, Kinzler KW, Vogelstein B (2006) The role of companion diagnostics in the development and use of mutation-targeted cancer therapies. Nat Biotechnol 24: 985-995

Perez-Soler R, Chachoua A, Hammond LA, Rowinsky EK, Huberman M, Karp D, Rigas J, Clark GM, Santabarbara P, Bonomi P (2004) Determinants of tumor response and survival with erlotinib in patients with non-small-cell lung cancer. J Clin Oncol 22: 3238-3247

Sakurada A, Lara-Guerra H, Liu N, Shepherd FA, Tsao MS (2008) Tissue heterogeneity of EGFR mutation in lung adenocarcinoma. J Thorac Oncol 3: $527-529$

Sharma SV, Bell DW, Settleman J, Haber DA (2007) Epidermal growth factor receptor mutations in lung cancer. Nat Rev Cancer 7: 169-181
Sordella R, Bell DW, Haber DA, Settleman J (2004) Gefitinib-sensitizing EGFR mutations in lung cancer activate anti-apoptotic pathways. Science 305: $1163-1167$

Takano T, Ohe Y, Sakamoto H, Tsuta K, Matsuno Y, Tateishi U, Yamamoto S, Nokihara H, Yamamoto N, Sekine I, Kunitoh H, Shibata T, Sakiyama T, Yoshida T, Tamura T (2005) Epidermal growth factor receptor gene mutations and increased copy numbers predict gefitinib sensitivity in patients with recurrent non-small-cell lung cancer. J Clin Oncol 23: $6829-6837$

Taron M, Ichinose Y, Rosell R, Mok T, Massuti B, Zamora L, Mate JL, Manegold C, Ono M, Queralt C, Jahan T, Sanchez JJ, Sanchez-Ronco M, Hsue V, Jablons D, Sanchez JM, Moran T (2005) Activating mutations in the tyrosine kinase domain of the epidermal growth factor receptor are associated with improved survival in gefitinib-treated chemorefractory lung adenocarcinomas. Clin Cancer Res 11: 5878-5885

Tokumo M, Toyooka S, Kiura K, Shigematsu H, Tomii K, Aoe M, Ichimura K, Tsuda T, Yano M, Tsukuda K, Tabata M, Ueoka H, Tanimoto M, Date H, Gazdar AF, Shimizu N (2005) The relationship between epidermal growth factor receptor mutations and clinicopathologic features in non-small cell lung cancers. Clin Cancer Res 11: 1167-1173

Tortola S, Steinert R, Hantschick M, Peinado MA, Gastinger I, Stosiek P, Lippert H, Schlegel W, Reymond MA (2001) Discordance between K-ras mutations in bone marrow micrometastases and the primary tumor in colorectal cancer. J Clin Oncol 19: 2837-2843

Tsao AS, Tang XM, Sabloff B, Xiao L, Shigematsu H, Roth J, Spitz M, Hong WK, Gazdar A, Wistuba I (2006) Clinicopathologic characteristics of the EGFR gene mutation in non-small cell lung cancer. J Thorac Oncol 1: $231-239$

Tsao MS, Sakurada A, Cutz JC, Zhu CQ, Kamel-Reid S, Squire J, Lorimer I, Zhang T, Liu N, Daneshmand M, Marrano P, da Cunha Santos G, Lagarde A, Richardson F, Seymour L, Whitehead M, Ding K, Pater J, Shepherd FA (2005) Erlotinib in lung cancer - molecular and clinical predictors of outcome. $N$ Engl J Med 353: 133 - 144

van 't Veer LJ, Dai H, van de Vijver MJ, He YD, Hart AA, Mao M, Peterse HL, van der Kooy K, Marton MJ, Witteveen AT, Schreiber GJ, Kerkhoven RM, Roberts C, Linsley PS, Bernards R, Friend SH (2002) Gene expression profiling predicts clinical outcome of breast cancer. Nature 415: $530-536$

van Zandwijk N, Mathy A, Boerrigter L, Ruijter H, Tielen I, de Jong D, Baas P, Burgers S, Nederlof P (2007) EGFR and KRAS mutations as criteria for treatment with tyrosine kinase inhibitors: retro- and prospective observations in non-small-cell lung cancer. Ann Oncol 18: 99-103

Van't Veer LJ, Weigelt B (2003) Road map to metastasis. Nat Med 9: $999-1000$

Yokota J, Kohno T (2004) Molecular footprints of human lung cancer progression. Cancer Sci 95: 197-204 